\title{
DRYING KINETICS AND SORPTION BEHAVIOR OF TWO VARIETIES BANANA (SAGOR AND SABRI) OF BANGLADESH
}

\author{
M.H. Rahman ${ }^{1}$, M.W. Ahmed ${ }^{2 *}$ and M.N. Islam ${ }^{3}$ \\ ${ }^{1}$ Police Super Office, Jhalokathi, Bangladesh \\ ${ }^{2}$ Department of Agricultural Engineering, Sher-e-Bangla Agricultural University \\ Dhaka-1207, Bangladesh \\ ${ }^{3}$ Department of Food Technology and Rural Industries, Bangladesh Agricultural University, Bangladesh
}

\begin{abstract}
The study was concerned with determining the drying kinetics and sorption behavior of two varieties ripe banana of Bangladesh namely, Sagor and Sabri. The fresh ripe banana collected from the local market were sliced into three different thicknesses $(4 \mathrm{~mm}, 6 \mathrm{~mm}$ and $8 \mathrm{~mm})$ and dried at $45^{\circ} \mathrm{C}, 55^{\circ} \mathrm{C}$ and $65^{\circ} \mathrm{C}$ in a cabinet dryer. The result showed that the drying rate increases with the increase in temperature and decreases with the increase in slice thickness. The sorption properties of dried banana were studied over a wide range of water activity $(0.11-0.93)$. The $B E T$ and GAB models were fitted to the sorption data. It was found that both varieties gave sigmoid (type II) shape isotherm and GAB equation gave the much higher value of monolayer moisture content compared to BET equation. The chemical compositions of fresh and dried banana were determined. The dried products gave substantially higher solid content as well as protein, ash and carbohydrate.
\end{abstract}

Keywords: Drying rate, Sagor, Sabri, temperature, thickness, moisture sorption.

\section{INTRODUCTION}

Banana (Musa sapientumL.) is an important fruit crop in Bangladesh. It belongs to the family Musacaceae. There are only two genera, viz. Enste and Musa with about 50 species in this family (Azam et al.,2010). Sagor (AAA genome) and Sabri (AAB genome) is the most popular dessert banana and widely grown in the north and western areas in Bangladesh (Islam and Hoque, 2004). Bangladesh ranks $14^{\text {th }}$ among the top 20 banana producing countries in the world and this country are producing nearly 1.00 million tons of bananas annually (Hossain, 2014). Banana represents $20 \%$ of all fruit crops and only fruit available year round in Bangladesh (BBS, 2014).

\footnotetext{
* Corresponding author email: wahmed.sau014@gmail.com
} 
Sagor and Sabri are most cultivated variety in Bangladesh and accounts for $30.8 \%$ and $21.2 \%$ of total banana production (Fonsa et al., 2017). Banana is rich in carbohydrate and also contains appreciable amount of fiber, polyphenols, antioxidants, vitamins and minerals such as $\mathrm{K}, \mathrm{P}, \mathrm{Ca}$ and $\mathrm{Fe}$ (Zotarelli et al.,2012; Silva et al.,2014). Due to high moisture content, banana is very susceptible to deterioration (Monteiro et al.,2016) and at room temperature $\left(20^{\circ} \mathrm{C}\right)$ it cannot be preserved more than 7 days from the ripening initiation (Islam et al.,2012). Drying of ripe banana is an interesting alternative to reduce losses and to improve food commercial value which makes this process, a potential agribusiness (Aurore et al., 2009). The ripe banana powder can be used as an ingredient in the low calorific bread, biscuit and spaghetti production (Silva et al.,2014) as well an active ingredient of antimicrobial film production (Orsuwan et al.,2016).

Historically conventional hot air drying has been the most common fruits and vegetable drying technique which requires less area and no weather dependence. Though hot air dehydration is a good technique for faster reduction of moisture, the dehydration kinetics greatly depends on air properties (temperature, humidity, velocity etc.) and the properties of material to be dried (Babalis and Belessiotis, 2004). Controlling of moisture content in dried foods during processing and storage is very important because water has many roles in biochemical reactions and quality of foods.From several researches it has been proven that the knowledge of sorption isotherm is extremely important in food dehydration, especially to determine end product of drying it achieve shelf-stable dehydrated foods (Cardoso and Pena, 2014). A number of equations have been published by various researchers to describe the water sorption isotherms of dried products. BET (Brunauer-Emmett-Teller) and GAB (Guggenheim-Andersen-de Boer) equations are generally applied for the most food products (Rodríguezn et al., 2007). Published research has shown that, the monolayer value of GAB model is always higher than the BET monolayer value (Timmermann, 2003) whereas GAB found asthe bestmodel among of all models due to its applicability to a wide range of water activity (Zouet al.,2016)

Therefore, the goal of this work was the study of the influence of slice thickness and temperature in drying kinetics of bananas in a mechanical dryer, as well as knowing the proximate composition of fresh samples before drying. Sorption behavior of dried bananas was also studied as well as prediction of moisture adsorption by BET and GAB models.

\section{MATERIALS AND METHOD}

\section{Samples and Equipment}

Fresh bananas of Sagor (Musa sapientum, AAA genome) and Sabri(Musa sapientum, $A A B$ genome) were purchased from the local market (Mymensingh, Bangladesh). Fruit selection was done by visual inspection where initially ripened bananas were used for proximate composition analysis and drying. Cabinet dryer (Model OV-165, 
Size-three, Gallen Kamp Company) was used for the dehydration of banana slices. The dryer has a heater installation where the air blows by a fan over the trays containing the samples to be dried. The velocity of air was recorded $(0.6 \mathrm{~m} / \mathrm{sec})$ by an Anemometer, which was maintained throughout the drying period.

\section{Proximate Composition Analysis}

Fresh ripe banana of two varieties (Sagor and Sabri) were analyzed for moisture, carbohydrate, protein, fat and ash content as per the methods of AOAC (2016) and Ranganna (1992). All the trial were done in triplicate and the results were taken as the average value

\section{Mechanical drying}

Fresh Sagor and Sabri banana were sliced at $4 \mathrm{~mm}, 6 \mathrm{~mm}$ and $8 \mathrm{~mm}$ by potato slicer and placed in numbered trays of dryer. For observation of thickness and temperature effect on drying rate, banana slices were dried at three different temperatures $\left(45^{\circ} \mathrm{C}\right.$, $55^{\circ} \mathrm{C}$ and $\left.65^{\circ} \mathrm{C}\right)$ at constant air velocity $\left(0.6 \mathrm{~m} \mathrm{sec}^{-1}\right)$. The initial moisture content of all samples was determined previously. The mass change of samples during drying over specific time interval was recorded to calculate moisture ratio that needed to calculate the drying rate.

Fick's second law of diffusion is commonly applied for describing mass transfer during drying (Islam et al., 2012; Jena and Das, 2007). The expression is as follows-

$\frac{\delta M}{\delta T}=\Delta^{2} D_{e} M$

Where $\mathrm{M}$ is the moisture content (dry basis), $\mathrm{T}$ is the time(s), De is the effective diffusion co-efficient $\left(\left(\mathrm{m}^{2} \mathrm{~s}^{-1}\right)\right.$ and $\Delta$ is the mass transfer gradient.

To solve above unsteady state diffusion equation negligible external mass transfer resistance, negligible temperature gradient within the sample being dried and a constant diffusion co-efficient at any constant temperature is assumed. For drying from one major face, equation (1) was suggested by several researchers (AlMuhtaseb et al., 2010; Roberts et al., 2008) as follows

$M R=\frac{M_{t}-M_{e}}{M_{0}-M_{e}}=\frac{8}{\pi^{2}} \sum_{n=o}^{\infty} \frac{1}{(2 n+1)^{2}} \operatorname{Exp} .\left[\frac{-(2 n+1)^{2} \pi^{2} D_{e} t}{L^{2}}\right]$.

Where, $M_{o}$ is the initial moisture content (d.b), $M_{e}$ is the equilibrium moisture content (d.b), $\mathrm{M}_{\mathrm{t}}$ is the moisture content (d.b) at time, $\mathrm{t}$ and $\mathrm{n}$ is the order of equation.

For low $M_{e}$ values and for moisture ratio < 0.6 equation (2) is reduces to:

$M R=\frac{M_{t}}{M_{0}}=\frac{8}{\pi^{2}} e^{-\pi^{2} D_{e} t / L^{2}}=\frac{8}{\pi^{2}} e^{-m t}$ 
Rearranging equation (3) gives:

$$
\ln \frac{\mathrm{M}_{\mathrm{t}}}{\mathrm{M}_{0}}=\ln \frac{8}{\pi^{2}}-\mathrm{mt}
$$

Where,

$$
\mathrm{m}=\frac{\pi^{2} \mathrm{D}_{\mathrm{e}}}{\mathrm{L}^{2}}=\text { Drying rate constant, } \mathrm{sec}^{-1}
$$

Drying rate constant $(\mathrm{m})$ was obtained as the slope of line by plotting moisture ratio $(\mathrm{MR})$ against time $(\mathrm{t})$. Effective diffusion coefficient (De) was calculated by using drying rate constant $(\mathrm{m})$ and slab thickness $(\mathrm{L})$.

The temperature dependence of diffusion coefficient can be calculated using the Arrhenius equation (Aghbashlo et al., 2009; Mghazlia et al., 2017) as follows

$$
\ln \mathrm{D}_{\mathrm{e}}=\ln D_{0}-\frac{\mathrm{E}_{\mathrm{a}}}{\mathrm{R}\left(\mathrm{T}_{\mathrm{abs}}\right)^{2}}
$$

Where, $D_{o}$ is the Arrhenius equation constant, $E_{a}$ is the activation energy of the diffusion of water vapor $\left(\mathrm{Kcal} \mathrm{g}^{-1}-\mathrm{mol}\right), \mathrm{R}$ is the universal gas constant $(1.987 \mathrm{Kcal} \mathrm{g}$ ${ }^{1}$. mole ${ }^{\circ} \mathrm{K}$.) and $\mathrm{T}_{\mathrm{abs}}$ is the absolute temperature $\left({ }^{\circ} \mathrm{K}\right)$ of the drying air. The activation energy of diffusion was calculated from the slope of the plot of $1 \mathrm{nD}_{\mathrm{e}}$ against inverse absolute temperature (1/ $\mathrm{T}_{\mathrm{abs}}$ on linier co-ordinates. The rate constant from Fick's model (Equation 4), and the activation energy from Arrhenius model (Equation 5) were estimated by the linear regression procedure of Excel 2007.

\section{Analysis of sorption behavior}

The moisture sorption properties of dried bananas were determined at room $\left(25^{\circ} \mathrm{C}\right)$ temperature under conditions of various relative humidity $(11-93 \%$ R.H) in the vacuum desiccators. The various RH conditions were achieved in vacuum desiccators using saturated salt solutions (ASTM E104-02). The method involved putting accurately weighed $3 \mathrm{gm}$ dried and crushed sample in a previously weighed Petridish into desiccators contained saturated salt solutions. An external pump was used to evacuate the desiccators less than 50 torr. After placing into desiccators, the sample weight was taken continuously until it reached to a constant weight. All the trials were done in triplicate and the results were taken as average value.

The monolayer moisture content for the moisture adsorption process was determined using the BET and GAB linear model, shown in table 1, by linear regression using the Microsoft Office Excel 2007 software. The coefficient of determination $\left(\mathrm{R}^{2}\right)$ were used to compare the goodness of fit of both modes. 
Table 1. Models used to fit the sorption isotherms of banana flours

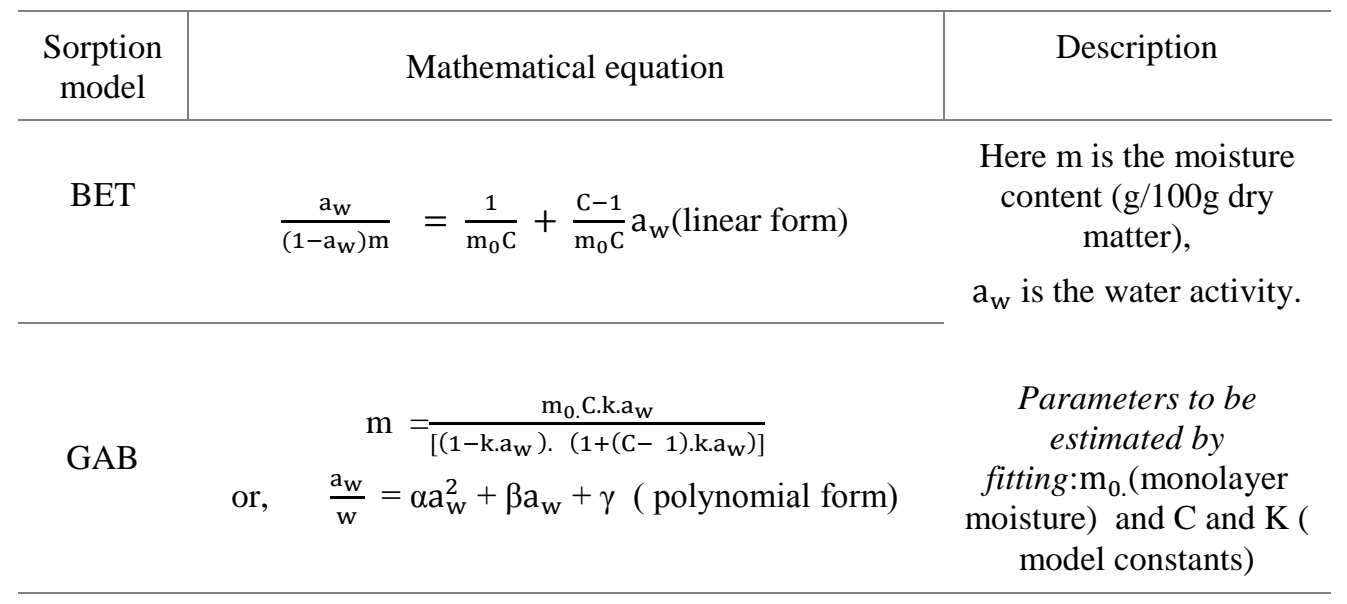

\section{RESULT AND DISCUSSION}

\section{Proximate composition of dried bananas}

Dried Sagor and Sabri banana slices were grinded to flour and analyzed for proximate analysis. The Proximate composition of banana flours of the two varieties is presented in Table 2 .

Table 2. Proximate compositions of dried Sagor and Sabri variety

\begin{tabular}{ccc}
\hline Components & Sagor variety & Sabri variety \\
\hline Moisture content $(\%$ d.b) & $17.65 \pm 0.19^{\mathrm{a}}$ & $17.77 \pm 0.22^{\mathrm{b}}$ \\
Protein $(\mathrm{N} \times 5.85)(\%)$ & $3.26 \pm 0.10^{\mathrm{a}}$ & $3.40 \pm 0.08^{\mathrm{b}}$ \\
Fat $(\%)$ & $0.06 \pm 0.07^{\mathrm{a}}$ & $0.07 \pm 0.04^{\mathrm{b}}$ \\
Ash $(\%)$ & $1.66 \pm 0.10^{\mathrm{a}}$ & $4.57 \pm 0.09^{\mathrm{b}}$ \\
$*$ Carbohydrate $(\%)$ & 95.04 & 91.96 \\
\hline
\end{tabular}

d.b: dry basis , N: Nitrogen content The values are mean \pm S.D of three independent determinations. The means with different superscripts in same row differ significantly $(\mathrm{p} \leq 0.05)$. Calculated value.

It was observed that dried Sagor variety gave slight lower moisture content $(17.65 \%$ d.b) than Sabri variety (17.77\% d.b) while carbohydrate content of Sagor variety is quite higher than that of Sabri variety $(95.04 \%$ vs. $91.96 \%$. In contrast to carbohydrate content, Sabri variety gave slight higher protein content $(3.40 \%$ vs. $3.26 \%)$, fat content $(0.07 \%$ vs. $0.06 \%)$ but more than double ash content ( $4.57 \%$ vs $1.66 \%$ ) compare to Sagor variety. Lower amount of fat content may be due to oxidation during drying while higher ash content may vary with stage of ripening. 
Some researchers investigated starch and sugar content separately which both are carbohydrates. Cardoso and Pena (2014) reported 70.07\% starch, 3.16\% ash, 4.89\% protein and $1.63 \%$ fat in dried banana powder. Starch (in terms of carbohydrate) content reduces and sugar content increases with the progress of ripening of banana (Cardoso and Pena, 2014). Menezes et al. (2011)found 3.14\% ash, $0.89 \%$ fat, $3.60 \%$ protein, $76.77 \%$ starch and $1.81 \%$ reducing sugars where Mota et al. (2000) reported $0.82 \%$ lipid and $2.6 \%$ protein for Sagor ( Musa spp. AAA) variety.

\section{Drying characteristics of banana slices}

\section{Thickness dependence of drying rate constant and drying time}

To observe the influence of thickness on drying rate constant, $4 \mathrm{~mm}, 6 \mathrm{~mm}, 8 \mathrm{~mm}$ thick banana slices were dried in a mechanical dryer at constant dry bulb temperature of $65^{\circ} \mathrm{C}$. The results were analyzed using equation (4) and the moisture ratio (MR) versus drying time ( $\mathrm{t}$, in hour) was plotted on a semi-log co-ordinate and obtained following equations and figures $(1 \& 2)$. For all curves co-efficient of determination $\left(\mathrm{R}^{2}\right)$ was more than 0.96 that indicates very well linear fit of data.

For sagor variety

$$
\begin{aligned}
& M R=0.8771 \mathrm{e}^{-0.298 \mathrm{t}} \text { (for } 4 \mathrm{~mm} \text { slices) } \\
& M R=0.9366 \mathrm{e}^{-0.221 \mathrm{t}} \text { (for } 6 \mathrm{~mm} \text { slices) } \\
& M R=1.0018 \mathrm{e}^{-0.153 \mathrm{t}} \text { (for } 8 \mathrm{~mm} \text { slices) }
\end{aligned}
$$

For sabri variety

$$
\begin{aligned}
& M R=0.8917 \mathrm{e}^{-0.33 t} \quad \text { (for } 4 \mathrm{~mm} \text { slices) } \\
& M R=0.9199 \mathrm{e}^{-0.249 t} \text { (for } 6 \mathrm{~mm} \text { slices) } \\
& M R=1.0172 \mathrm{e}^{-0.185 t} \quad \text { (for 8mm slices) }
\end{aligned}
$$

Obtained equation implies that drying rate constant decreasing with increasing slice thickness.

From Fig. $1 \& 2$ it was observed that thickness had profound influence on drying time. When thickness of the sample at a constant temperature increased, the drying time to a specific moisture ratio also increased with resultant decrease in drying rate constant. It was also noticeable that for a self-stable moisture ratio (MR $=0.7) 4 \mathrm{~mm}$ thick slice required the least time $(2.00 \mathrm{hr})$ followed by $6 \mathrm{~mm}$ thick slice $(3.1 \mathrm{hr})$, while the highest time $(4.9 \mathrm{hr})$ was required to dry $8 \mathrm{~mm}$ thick slice of sagor sample at $65^{\circ} \mathrm{C}$. But, in case of sabri this values were found $1.9 \mathrm{hr}, 2.9 \mathrm{hr}$ and $4.7 \mathrm{hr}$ respectively. It has been reported by several researches similar influence of slice thickness on drying rate constant. Ertekin(2004) and Islam (2012) also reported that drying rate constant decreases with increase of slice thickness. 


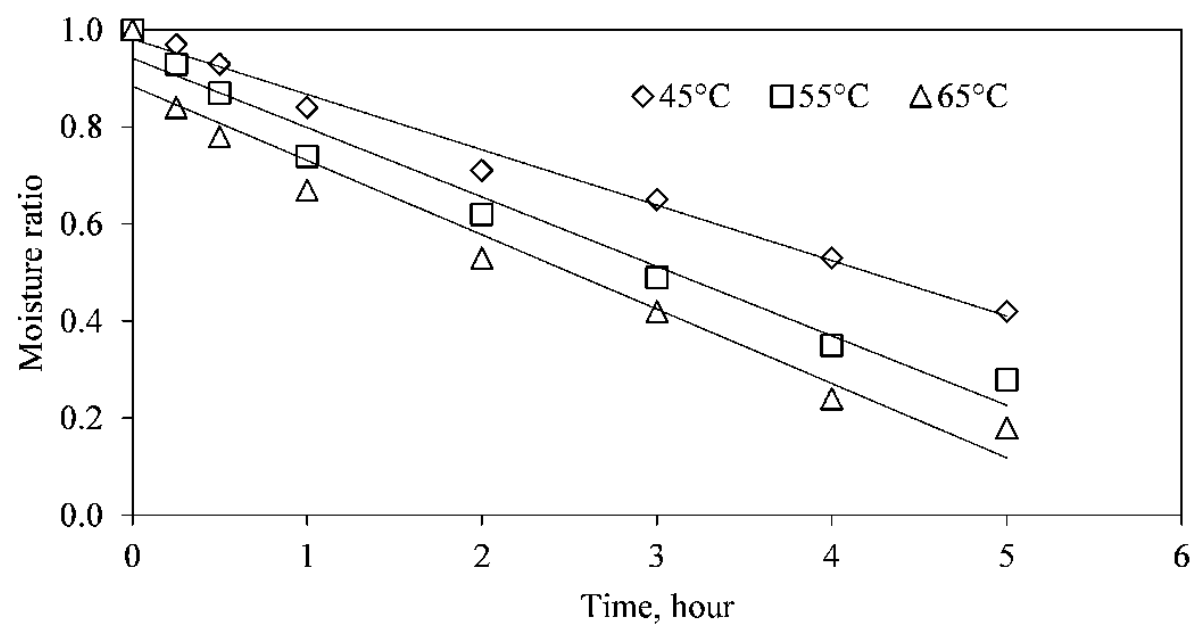

Figure 1. Influence of thickness on drying rate of banana (Sagor) at $65^{\circ} \mathrm{C}$ in a mechanical dryer

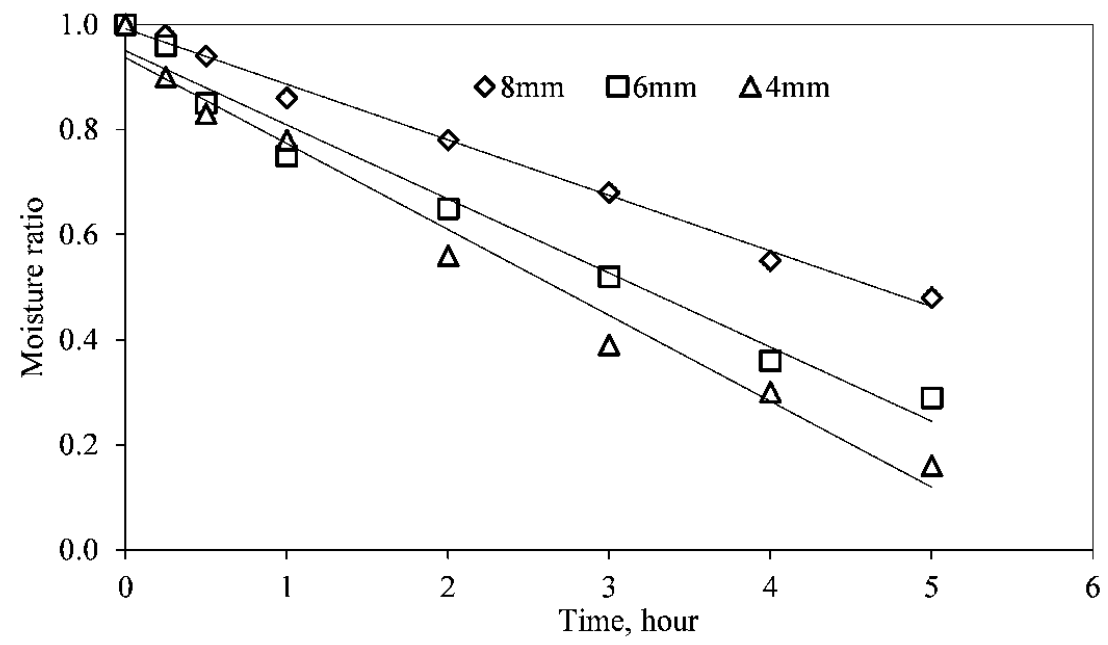

Figure 2. Influence of thickness on drying rate of banana $(\mathrm{Sabri})$ at $65^{\circ} \mathrm{C}$ in a mechanical dryer 


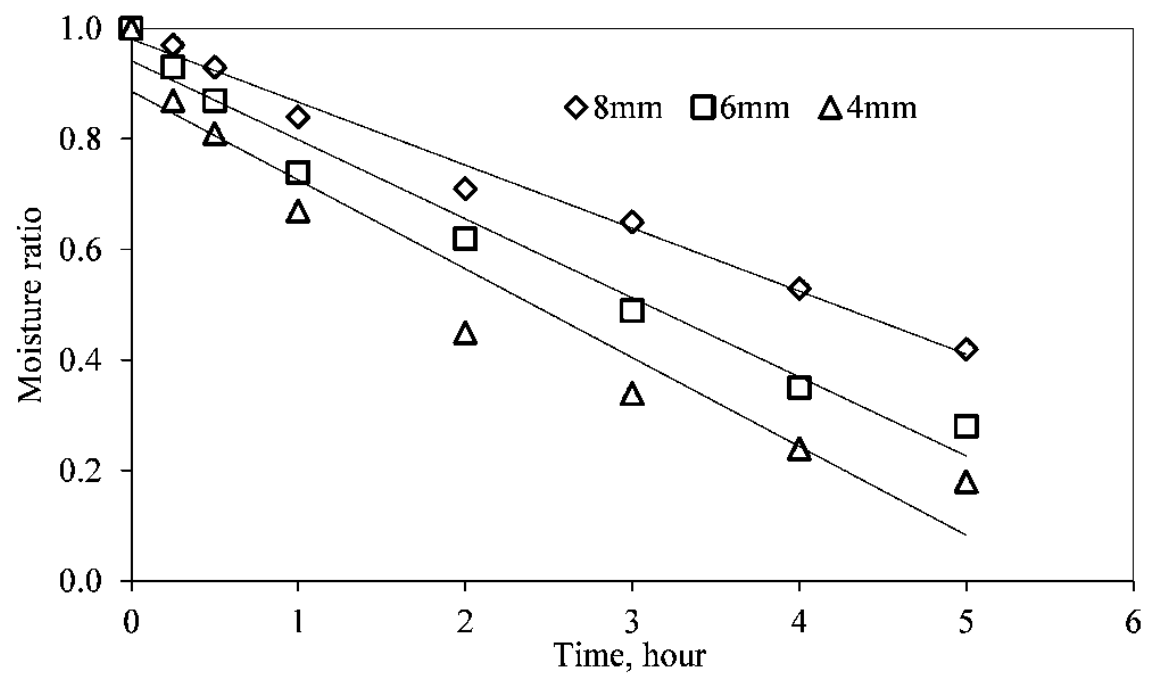

Figure 3. Influence of temperature on drying rate for $4 \mathrm{~mm}$ thick slice of Sagor variety

\section{Effects of temperature on drying rate}

To analyze the effect of temperature on drying rate, banana $4 \mathrm{~mm}$ slices were dried in a cabinet dryer at three different air-dry bulb temperatures $\left(45^{\circ} \mathrm{C}, 55^{\circ} \mathrm{C}, 65^{\circ} \mathrm{C}\right)$. The MR values were plotted against drying time (t) on semi-log coordinates those are shown in Fig. 3 \& 4. Drying rate constants were calculated as per equation (4) and diffusion co-efficient of different banana slices were calculated from the rate constant and slice thickness. The activation energy as the parameter of temperature influence on drying kinetics was calculates as per equation (5) and given in table 3.

Table 3. Diffusion co-efficient and activation energy of $4 \mathrm{~mm}$ thick banana slices under different drying conditions

\begin{tabular}{|c|c|c|c|c|c|}
\hline $\begin{array}{l}\text { Thickness } \\
\text { (cm) }\end{array}$ & Variety & $\begin{array}{c}\text { Temperature, } \\
{ }^{\circ} \mathrm{C}\end{array}$ & $\begin{array}{l}\text { Rate constant, } \\
\mathrm{cm}\left(\sec ^{-1}\right)\end{array}$ & $\begin{array}{c}\text { Diffusion co- } \\
\text { efficient } \\
\left(\mathrm{cm}^{2} \mathrm{sec}^{-1}\right)\end{array}$ & $\begin{array}{c}\text { Activation } \\
\text { Energy, Ea } \\
\text { (Kcal/g.mol) }\end{array}$ \\
\hline \multirow{6}{*}{0.4} & \multirow{3}{*}{ Sagor } & $45^{\circ} \mathrm{C}$ & $5.64 \times 10^{-5}$ & $9.14 \times 10^{-7}$ & \multirow{3}{*}{3.65} \\
\hline & & $55^{\circ} \mathrm{C}$ & $7.00 \times 10^{-5}$ & $1.13 \times 10^{-6}$ & \\
\hline & & $65^{\circ} \mathrm{C}$ & $8.27 \times 10^{-5}$ & $1.32 \times 10^{-6}$ & \\
\hline & \multirow{3}{*}{ Sabri } & $45^{\circ} \mathrm{C}$ & $6.74 \times 10^{-5}$ & $1.09 \times 10^{-6}$ & \multirow{3}{*}{3.11} \\
\hline & & $55^{\circ} \mathrm{C}$ & $8.36 \times 10^{-5}$ & $1.36 \times 10^{-6}$ & \\
\hline & & $65^{\circ} \mathrm{C}$ & $9.17 \times 10^{-5}$ & $1.49 \times 10^{-6}$ & \\
\hline
\end{tabular}


Fig. 3 and Fig 4 and table 3 imply that when temperature increased, gradient or slope of the line also increased with respect to period of drying.This can be explained also by diffusion co-efficient. Table 3 shows that diffusion co-efficient increases with increase of time for a specific slice thickness. It implies that at specific moisture ratio (MR) drying rate increases with increasing temperature. At the very high temperature and low humidity, drying rate may initially increase, but as drying progresses resultant case hardening, that would reduce drying rate drastically and deteriorate the quality of the product. Thus selection of optimum temperature for drying is very significant during drying particularly mechanical drying with counter current operation (Islam,1980).

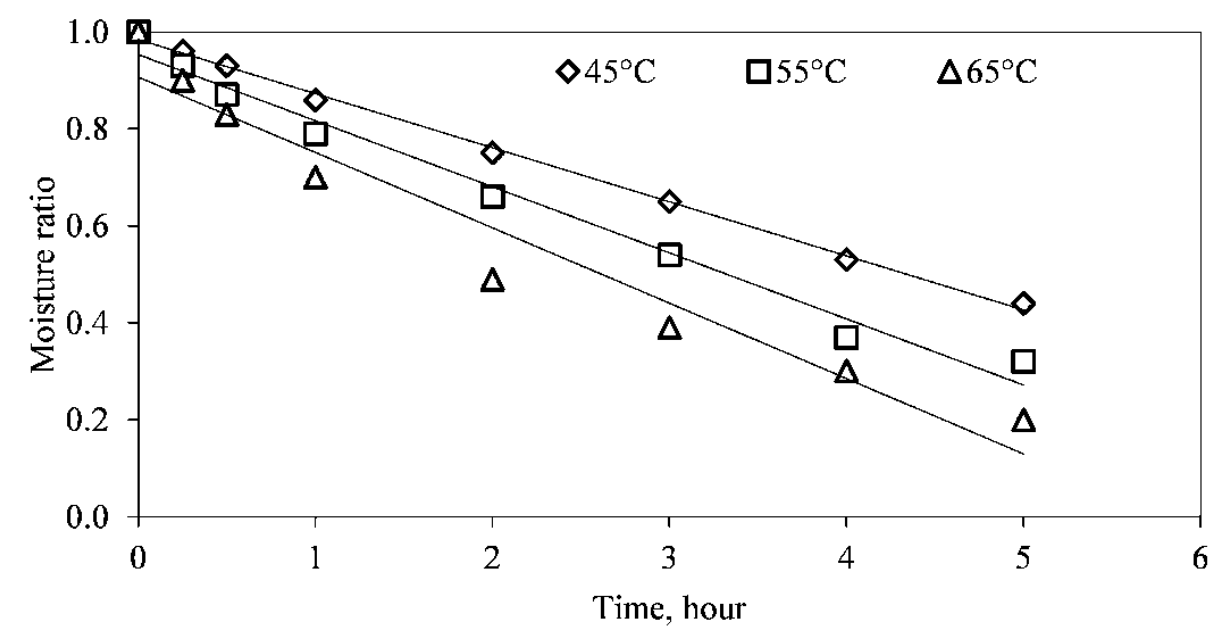

Figure 4. Influence of temperature on drying rate for $4 \mathrm{~mm}$ thick slice of Sabri variety

The amount of activation energy indicated the temperature sensitivity and energy needed to initiate moisture diffusion within the slice. It was observed that activation energy for $4 \mathrm{~mm}$ thick sagor variety $\left(3.65 \mathrm{Kcal} \mathrm{g}^{-1} \mathrm{~mol}\right)$ is higher than $4 \mathrm{~mm}$ thick slice of sabri variety $\left(3.65 \mathrm{Kcal} \mathrm{g}^{-1} \mathrm{~mol}\right)$. The difference in activation energy may be due to difference in their cellular structure and chemical composition (Islam, 1980). However our calculated activation energy is within the general range of 1.53-12.23 Kcal mol ${ }^{-1}$ reported by Zogzas et al.(1996) and nearer to mango powder (3.48 Kcal $\left.\mathrm{mol}^{-1}\right)$ reported by Kabiru et al.(2013) and grape seed (3.66 Kcal g $\left.{ }^{-1} \mathrm{~mol}\right)$,reported by Roberts et al.(2008). 


\section{Sorption behavior of dried bananas}

The adsorption isotherms for dried Sagor and Sabri varieties at $25{ }^{\circ} \mathrm{C}$ are shown in Figure 5. The sorption behavior of bananas can be adequately represented by a sigmoid shape, characteristic of a type II isotherm. According to the classification of BET (Brunauer et al., 1938), most products exhibit an S- shaped isotherm.

Figure 5 shows, there is a little moisture absorption tendency at water activity below 0.75 and the sample absorbed higher amount of moisture at water activity above 0.75 . At the water activity of 0.93 , samples absorbed highest moisture. The exponential behavior of moisture absorption of both flours indicates the flour would be required improved storage condition mainly control humid environment. The lower portion of the isotherms indicates microbial stability at lower humid condition especially below 0.6. In sorption analysis it was observed that though initial moisture content was quite nearer both varieties followed almost same trend of moisture absorption during entire period. These results were also compared with those obtained by different authors (Cardoso and Pena, 2014; Silva et al., 2014) and a good agreement, with some differences were found between them.

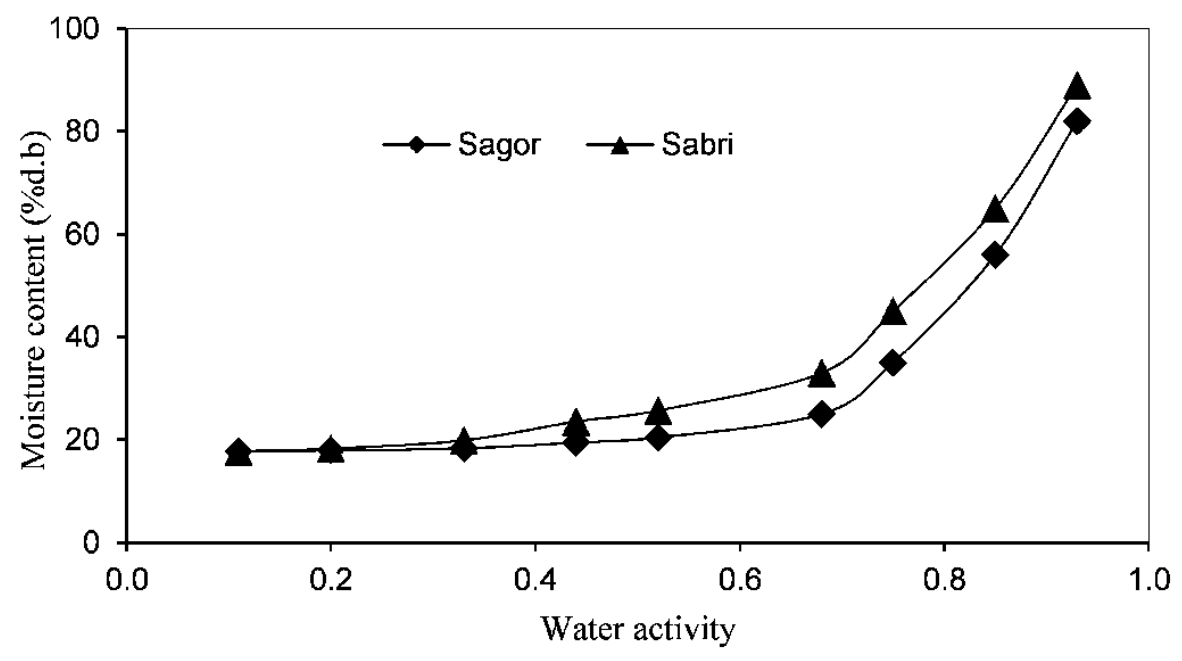

Figure 5. Sorption behavior of banana flours

\section{Modeling of sorption data}

BET (Brunauer, Emmet, and Teller) and GAB isotherm (Guggenheim-Anderson-De Bore) models were used to find monolayer moisture contents are shown in table 4. The value of regression coefficient $\left(\mathrm{R}^{2}\right)$ indicates the goodness of fit and effective model for sorption isotherm prediction of banana. 
It was found that the calculated monolayer moisture content using GAB model for both varieties is litter higher than that of the BET model. According to regression coefficient value $\left(\mathrm{R}^{2}>0.99\right)$, GAB model provided the best fit to the absorption of both Sagor and Sabri variety. Cardoso and Pena (2014) were made a similar recommendation for GAB and Oswin model in case banana (Musa spp. AAA) flour. Similar observations were made by Silva (2014) and Timmermann (2003) for GAB model.

Table 4. Model parameters for sorption isotherm of banana

\begin{tabular}{c|cc|c|c}
\hline \multirow{2}{*}{ Sorption model } & $\begin{array}{c}\text { Monolayer moisture content in \%d.b }\left(\mathrm{R}^{2}\right. \\
\text { value of regression line })\end{array}$ & \multicolumn{2}{|c}{ Constant (C) } \\
\cline { 2 - 5 } & Sagor & Sabri & Sagor & Sabri \\
\hline BET & $12.73(0.976)$ & $10.042(0.987)$ & 31.692 & 91.273 \\
GAB & $13.34(0.997)$ & $10.064(0.998)$ & 46.559 & 87.408 \\
\hline
\end{tabular}

\section{CONCLUSION}

The study was conducted to determine the effects of thickness and temperature on drying rate of ripe bananas (Sagor and Sabri varities) during mechanical drying. A smaller thickness of $4 \mathrm{~mm}$ with higher temperature of $65^{\circ} \mathrm{C}$ was found the best condition for drying of both verities. Proximate composition of dried bananas was also investigated. According to the moisture absorption data, both varieties gave sigmoid (type II) shape isotherm and more susceptible to decay after 0.75 water activity. Finally, the GAB model was highlighted over BET model for its ability to predict moisture sorption isotherm of both banana flours at room temperature $\left(25^{\circ} \mathrm{C}\right)$.

\section{REFERENCES}

Aghbashlo, M., Kianmehr, M.H., and Arabhosseini, A. (2009, March). Performance analysis of drying of carrot slices in a semi-industrial continuous band dryer. Journal of Food Engineering, 91(1), 99-108.

Al-Muhtaseb, A.H., Al-Harahsheh, M., Hararah, M., and Magee, T. (2010). Drying characteristics and quality change of unutilized-protein rich-tomato pomace with and without osmotic pre-treatment. Industrial Crops and Products, 31, 171-177.

AOAC. (2016). Association of Official Analytical Chemists, 20th edition. www.aoac.org

Aurore, G., Parfaitb, B., and Fahrasmane, L. (February 2009). Bananas, raw materials for making processed food products. Trends in Food Science \& Technology, 20(2), 78-91.

Azam, F., Islam, S., Rahmatullah, M., and Zaman, A. (2010). Clonal propagation of banana (Musa spp.) cultivar 'BARI-1' (AAA genome, Sapientum Subgroup). International Conference on Banana and Plantain in Africa on Harnessing International Partnerships to Increase Research Impact, (pp. 537-544). Leuven, Belgium. 
Babalis, S.J., and Belessiotis, V.G. (2004). Influence of the drying conditions on the drying constants and moisture diffusivity during the thin-layer drying of figs. Journal of Food Engineering, 65(3), 449-458.

BBS. (2014). Bangladesh Bureau of Statistics and Information, Statistics and Informatics Division. Dhaka: Ministry of planning, Bangladesh.

Brunauer, S., Emmett, E.T., and Teller, E. (1938). Journal of American chemical society, 63, 309.

Cardoso, J., and Pena, R.D. (2014). Hygroscopic behavior of banana (Musa ssp. AAA) flour indifferent ripening stages. food and bioproducts processing, 92, 73-79.

Cardoso, J.M., and Pena, R.D. (2014). Hygroscopic behavior of banana (Musa ssp. AAA) flour indifferent ripening stages. food and bioproducts processing, 92, 73-79.

Ertekin, C., and Yaldiz, O. (2004). Drying of eggplant and selection of a suitable thin layer drying model. Journal of Food Engineering, 63(3), 359-359.

Fonsah, E., Manower, T., Hussain, A., Chattapadhyad, S., Islam, S., Islam, M.S., and Amin, B. (2017). Factors Affecting Banana Agricultural Value Chain in Bangladesh. Journal of Food Distribution Research, 48(1), 22-32.

Hossain, M. (2014). A study of banana production in bangladesh: area, yield and major constraints.ARPN Journal of Agricultural and Biological Science, 9(6), 206-210.

Islam, S., and Hoque, M. (2004). Status of banana production in Bangladesh. Proceedings of the 2nd BAPNET Steering Committee meeting, Jakarta (IDN) (pp. 33-41). Los Baños (PHL): INIBAP-ASPNET.

Islam, M.N. (1984). Kinetic analysis of air drying of potato: traditional and improved methodsl. Journal of Agricultura Engineering, 12, 3-11.

Islam, M.S., Haque, M.A., and Islam, M.N. (2012). Effects of Drying Parameters on Dehydration of Green Banana (Musa sepientum) and its Use in Potato (Solanum tuberosum) Chips Formulation. The Agriculturists, 10(1), 87-97.

Jena, S., and Das, H. (2007). Modelling for vacuum drying characteristics of coconut presscake. Journal of food engineering, 79, 92-99.

Kabiru, A.A., Joshua, A.A., and Raj, A.O. (2013). Drying Kinetics of Mango (Mangifera Indica). International Journal of Research and Reviews in Applied Sciences, 15 (1): 41-51.

Menezes, E., Tadini, C., Tribess, T., Zuleta, A., Binaghi, J., Pak, N., and Lazolo, F. (2011). Chemical composition and nutritional value of unripe banana flour (Musa acuminata, var. Nanicão). Plant. Journal of human nutrition, 231-237.

Mghazlia, S., Ouhammou, M., Hidara, N., Lahninea, L., Idlimam, A., and Mahrouz, M. (2017). Drying characteristics and kinetics solar drying of Moroccan rosemary leaves. Renewable Energy, 108, 303-310.

Monteiro, R.L., Carciofi, B.A., and Laurindo, J.B. (2016). A microwave multi-flash drying process for producing crispy bananas. Journal of Food Engineering 178, 1-11.

Mota, R., Lajolo, F., Ciacco, C., and Cordenunsi, B. (2000). Composition and functional properties of banana flour from Different Varieties. Starch, 52(2-3), 63-65. 
Orsuwan, A., Shankar, S., Wang, L.-F., Sothornvit, R., and Rhim, J.W. (2016). Preparation of antimicrobial agar/banana powder blend films reinforced with silver nanoparticles. Food Hydrocolloids, 60, 476-485.

Ranganna, S. (1992). Manual of Analysis of Fruits and Vegetable Products. $2^{\text {nd }}$ edition.

Roberts, J.S., Kidd, D.R., and Padilla-Zakour, O. (2008). Drying kinetics of grape seeds. Journal of Food Engineering, 89(4), 460-465.

Roberts, J.S., Kidd, D.R., and Zakour, P. (2008). Drying kinetics of grape seeds. Journal of Food Engineering, 89, 460-465.

Rodríguez-Aragón, L.J., and López-Fidalgo, J. (2007). T-, D- and c-optimum designs for BET and $\mathrm{GAB}$ adsorption isotherms. Chemometrics and Intelligent Laboratory Systems, 89(1), 36-44.

Silva, W.P., e Silva, C.M., Gama, F.J., and Gomes, J.P. (2014). Mathematical models to describe thin-layer drying and to determine drying rate of whole bananas. Journal of the Saudi Society of Agricultural Sciences, 13, 67-74.

Timmermann, E.O. (2003). Multilayer sorption parameters: BET or GAB values? Colloids and Surfaces A: Physicochemical and Engineering Aspects, 220(1-3), 235-260.

Zogzas, N.P., Maroulis, Z. and Kouris, M. (1996). Moisture diffusivity data compilation in foodstuffs. Drying Technology, 14, 2225-2253.

Zotarelli, M., Porciuncula, B., and Laurindo, J. (2012). A convective multi-flash drying process for producing dehydrated crispy fruits. Journal of Food Engineering, 108, 523531.

Zou, L., Gong, L., Xu, P., Feng, G., and Liu, H. (2016). Modified GAB model for correlating multilayer adsorption equilibrium data. Separation and Purification Technoly 161(17): $38-43$. 